\title{
Students in the Role of Journalists: School Newspaper Publications about the Mass Media
}

\author{
Lina P. Valsamidou, (Corresponding author) \\ Communication and Journalism, Open University of Cyprus \\ Xatzimaloussi 1, 59200 Naoussa, Greece
}

Tel: 30-233-202-9585 E-mail:pvalsamidou@gmail.gr

\begin{abstract}
Argyris Kyridis, Professor
Department of Pre-School Education, Aristotle University of Thessaloniki University Campus - Faculty of Education, 54124 Thessaloniki, Greece

Tel: 30-231-099-5961Ｅ-mail: akiridis@nured.auth.gr
\end{abstract}

\author{
Received: February 11, 2012 Accepted: March 1, 2012 Published: May 1, 2012 \\ doi:10.5296/jse.v2i2.1377 URL: http://dx.doi.org/10.5296/jse.v2i2.1377
}

\begin{abstract}
A school newspaper is the quintessential children's school medium of mass communication, where children act as transmitters and receivers simultaneously but essentially act as journalists. So how do students-journalists face the Media in their own Medium, the school newspaper? What Media issues might occupy the school-editor community and, furthermore, how are these distinguished on the basis of "old/traditional" and "new" Media, or on the basis of print and electronic Media? We have searched out and catalogued the publications of school newspapers about the Mass Media in an attempt to elaborate on the kind and content of these publications. This will clearly highlight and manifest on one hand the Media apperceptions of the editors both from the social and the school environment, and on the other hand their critical attitude and position towards the Media.
\end{abstract}

Key words: School newspapers, Mass Media, Scholastic journalism 


\section{Introduction}

The publication of a school newspaper, already from kindergarten, was a key point in Freinet's pedagogy who pointed out that writing makes sense only when individuals must resort to it in order to convey their thoughts where their voices can't reach, beyond the school borders (Freinet, 1977:48), whereas he stressed the fact that a newspaper constitutes a network of natural interests for students and its mission in the school community and the broader society adds a maximum of intensity to the desire to be heard at a distance (Freinet, 1977:49), which is essential for children. The educational value of the class newspaper was also highlighted by Alberti (1986:89), who underlined that its value is of great importance as a newspaper is published in order to communicate thoughts and experiences both from inside and outside the school. Writing acquires a different sense as pupils write about someone or something, and not just to practice. As a consequence, the publication of a newspaper constitutes an activity that is particularly favourable to socialization and learning.

Children write about their classmates, parents, neighbours, about children from other schools and their texts become an opportunity for discussion and communication. For the needs of the newspaper, children become reporters, observers, or even at the same time acting persons in the events of school and social life. In this way they participate in a social "dialogue" choosing to write what in their opinion would be interesting to communicate to their classmates, their teachers and parents. Through the newspaper, children make an effective use of a communicative discourse that aims at convincing, moving, entertaining or all of the above according to the occasion. Students write various texts for the school newspaper that they publish in order to air their considerations, their apprehensions and troubles. All of the above mentioned occasions are real instances that form a part of social and school life by extension (Adaloglou, 1994:24-25).

According to Graff (2003), students' participation in publishing activities is an excellent opportunity to assess their entire academic progress. Bowen and Tantillo (2002) claim that scholastic journalism helps students develop their critical thinking, their ability to communicate and to be better, active citizens, whereas according to Poslaniek (1990:139-140) the school newspaper belongs to what he calls "empowering animations" ("Animations responsabilisantes"); it is a "product" that is proposed to a heterogeneous and demanding audience, through which the citizenship, not the pupilness is under evaluation. Furthermore, Kolodzy (2006:248) calls the children journalists "kid (citizen) reporters" and notes the practice of certain Media, such as $\mathrm{BBC}$ for children, to entice children of all ages to participatory journalism.

Thus, in the frame of the school newspaper, students are invited through interviews and researches (polls) to become directly acquainted with the social reality and its problems, to hear about the problems of their homeplace and their society from their fellow citizens, to process information and to reach their conclusions. In this way, by cultivating their critical ability, they construct a mechanism for controlling the information and the news that the Media provide them every day (Hatzopoulos et al, 2000).

In their school newspaper children act as reporters, as publishers and editors simultaneously, 
while they also have the dual role of the transmitter and the receiver. Their texts - verbal and visual - highlight and manifest what they think is important to be published and bequeathed to a wider audience.

It is an undeniable fact that today's children have extensive access to the Media. They are socialized in a world that is characterized by a broad spectrum of Media, ranging from the "old" (writing, book, television) to the "new" ones (video games, computers, internet) (Vryzas \& Tsitouridou, 2002). In the 21st century, in the Information and Knowledge Society, children should develop the necessary skills that will enable them to interact in a world that is characterized by the omnipresence of the Media. An indispensable capacity of a citizen that wishes to be considered as literate is the critical and analytical thinking ability of the Media messages, both as a receiver and as a transmitter. Through the columns of school newspapers, the current study searches for and catalogues the publications regarding the Mass Media "old/traditional" and "new", electronic and print - wishing to elaborate on the position, the kind and content of these publications in the quintessential school Media, thus reaching useful conclusions about the Media trends in print school journalistic practice.

\section{The Research}

In a wider definition, the Mass Media are all the impersonal Media of communication through which audio or visual or both kinds of messages are directly transmitted to audiences. Mass Media include the television, radio, cinema, newspapers, books and posters (bills, signs, etc) (Dictionary of Social Sciences, vol. II, 1972:532), as well as video games and CDs (Giddens, 2002:486; Psychogios, 2003:85).

According to Klapper (1949:3), the term indicates all the Mass Media in which there is a mechanism of impersonal reproduction interfering between the speaker and the audience. Based on that principle, the radio, screen, books and any other means of impersonal communication must come under the Mass Media. This definition excludes from the Mass Media only types of communications such as theatrical performances, personal conversations and public speeches (Dictionary of Social Sciences, vol. II, 1972:532). Buckingham (2003) defines Mass Media as all the modern Media of communication ranging from the television, cinema, radio, photography, newspapers and magazines, recorded music, video games and the internet.

The current study searches for and catalogues the publications of school newspapers regarding the Mass Media - "old/traditional" and "new", electronic and print Media wishing to reach useful conclusions about the position that the Media hold in print school journalistic practice, a practice that graphically reflects the Media apprehensions of the editors, both from the social and the school environment, which in their turn are clearly expressed in their journalistic work, the school/student newspaper, and reveal significant information about the school-communicative attitude/behaviour towards the Media.

\subsection{Purpose}

The purpose of this study is to investigate and catalogue the Media publications in the way they are highlighted through the columns of school newspapers, the quintessential school 
Mass Media.

More specifically, we search for and catalogue the kind and content of Media issues that editors choose to bring into the limelight, thus defining the identity of their own Medium by the choice of the articles. At the same time, we study the above-mentioned publications on the basis of the print-electronic Media and the "old/traditional"-"new" Media axis, in an attempt to draw useful conclusions regarding the preferences of those involved in print scholastic journalism as to the kind and content of the articles chosen to be published in the school newspaper.

\subsection{Sample}

The sample of our research comprises 54 newspaper issues coming from 27 titles of Greek primary school newspapers (Appendix 1) that were published in 2005-2007. Two issues of each title were selected randomly from the abovementioned period and the 112 Media publications (coming from 49 issues $-90,74 \%$ - that containing Media publications) in total were studied, both from the front page and the inside pages.

\section{Methodology}

The method employed for the process of our sample was content analysis (Berelson, 1952; De Sola Pool, 1959; Krippendorff, 1980; Weber, 1990²; Palmquist, 1990). The publication was used as the unit of analysis. According to Berelson, content analysis is "a research technique for the objective, systematic, and quantitative description of the manifest content of communication", written or oral speech, with interpretation as the final goal Berelson, 1952:18). De Sola Pool (1959) provided a different dimension in content analysis noting that it is ideal for the study of concepts and semantic relationships contained in written or oral speech. Several years later, Palmquist used content analysis in written texts by students and teachers (Palmquist, 1990. Weber, $1990^{2}$ ). However, the French bibliography has provided another dimension to this method revitalizing both its techniques and its potential for use (Moscovici, 1970; Bandin, 1977; Grawitz, 1981; Veron, 1981; Mucchieli, 1988). As a research tool, content analysis presents the following advantages (Curley, 1990):

- It provides the possibility of combining quantitative and qualitative data

- Through discourse analysis it offers the possibility of detecting and recording certain forms of social interaction

- It provides the possibility of recording historical and cultural information

- It serves the purpose of recording and analyzing social doctrines

- It allows the exploration of concepts and the way social subjects perceive them.

An initial classification and quantitative analysis was performed on all the publications of our sample both on the front and the inside pages. The Media publications were subsequently indexed according to their position in the newspaper columns: a) Regular columns, b) Random publications. 


\section{Macrothink}

Journal of Studies in Education

ISSN 2162-6952 2012, Vol. 2, No. 2

Next, publications based on their content and title, were codified in the following categories and specific axes:

I) Categories

1. Book

2. Printing/writing

3. Newspapers

4. Television

5. Computers

6. Internet

7. Radio

8. Mobile phone

9. Cinema

10. DVD

11. Combination of Media

II) Axes

A. Old/traditional Media

B. New Media

C. Combination of old/traditional and new Media

III) Axes
A. Print Media
B. Electronic Media
C. Combination of print and electronic Media

\section{Results}

The results of the classification of all 112 publications as to the front page and the inside pages are demonstrated in table 1:

Table 1. Classification of Media publications according to the newspaper page

\begin{tabular}{|l|l|l|}
\hline Media publications & $\mathrm{n}$ & $\mathbf{\%}$ \\
\hline Total & 112 & 100 \\
\hline Front page & 6 & 5.36 \\
\hline Inside pages & 106 & 94.64 \\
\hline
\end{tabular}

The analysis of table 1 shows that the vast majority of publications regarding the Media 


\section{Macrothink}

$(94.6 \%)$ is found at the inside pages of school newspapers, whereas a small amount of $5.3 \%$ is on the front page.

The classification of 106 inside page publications as to their position in a) Regular columns and b) Random publications resulted in the formation of table 2:

Table 2. Classification of Media publications according to their position in the newspaper columns

\begin{tabular}{|l|l|l|}
\hline Position & $\mathrm{n}$ & $\%$ \\
\hline Regular columns & 14 & 13.20 \\
\hline Random publications & 92 & 86.79 \\
\hline Total & 106 & 100 \\
\hline
\end{tabular}

The examination of table 2 leads to the realization that a percentage of 13.2 of the publications is found in a Regular column about Media issues, whereas $86.7 \%$ are randomly distributed in the pages of the newspapers. The qualitative analysis of the sample demonstrated that all the Regular columns that we encountered belong to the Book category and refer to book recommendations/ presentations and book reviews of the editors.

More specifically, the collection and taxonomy of the publications according to the categories on the front page and the inside pages led to the formation of tables 3 and 4 respectively.

Table 3. Media publications in the front page

\begin{tabular}{|l|l|l|l|}
\hline $\mathrm{S} / \mathrm{N}$ & Categories & $\mathrm{n}$ & $\%$ \\
\hline 1 & Computer & 2 & 33.33 \\
\hline 2 & Book & 2 & 33.33 \\
\hline 3 & $\begin{array}{l}\text { Mobile } \\
\text { phone }\end{array}$ & 1 & 16.66 \\
\hline 4 & Television & 1 & 16.66 \\
\hline & Total & 6 & 100 \\
\hline
\end{tabular}

The examination of table 3 as to the front pages of the newspapers as well reveals that publications regarding Book and Computer come first with a percentage of 33.3, followed by both the publications regarding Television and Mobile phone which occupy the second position in the ranking $(16.6 \%)$. 
Table 4. Media publications in the inside pages

\begin{tabular}{|l|l|l|l|}
\hline $\mathrm{S} / \mathrm{N}$ & Categories & $\mathrm{n}$ & $\%$ \\
\hline 1 & Book & 36 & 33.96 \\
\hline 2 & Television & 19 & 17.92 \\
\hline \multirow{4}{*}{3} & Mobile phone & 10 & 9.43 \\
\cline { 2 - 4 } & Cinema & 10 & 9.43 \\
\hline \multirow{4}{*}{4} & Combination & 6 & 5.66 \\
\cline { 2 - 4 } & Internet & 6 & 5.66 \\
\cline { 2 - 4 } & Radio & 6 & 5.66 \\
\hline 5 & Computer & 5 & 4.71 \\
\hline 6 & Newspapers & 4 & 3.77 \\
\hline 7 & Printing/writing & 3 & 2.83 \\
\hline 8 & DVD & 1 & 0.94 \\
\hline & Total & 106 & 100 \\
\hline
\end{tabular}

It is clear from reading table 4 regarding the inside pages of newspapers as well, that $33.9 \%$ of the young journalists' publications is about Book (consequently rising to the first position in their thematic preferences), a $17.9 \%$ relates to Television and ranks second, a $9.4 \%$ about Cinema and Mobile Phone occupies the third position, whereas the Internet, Radio and the Combination of 2 or more Media claim the fourth position, all with a percentage of 5.6. The publications relating to Computers assume the fifth position with a percentage of 4.7, Newspapers rank sixth with $3.7 \%$, Printing/writing come eighth with $2.8 \%$ and finally comes DVD with a percentage of 0.9 .

The overall quantitative analysis of our sample on all pages (front and inside pages) led to the following taxonomy by categories, as shown in table 5, whereas the qualitative examination featured illuminating data as to the content of the publications and the writing sample of Media themes by the editors.

Table 5. Quantitative analysis by categories

\begin{tabular}{|l|l|l|l|}
\hline $\mathrm{S} / \mathrm{N}$ & Categories & $\mathrm{n}$ & $\%$ \\
\hline 1 & Book & 38 & 33.92 \\
\hline 2 & Television & 20 & 17.85 \\
\hline 3 & Mobile phone & 11 & 9.82 \\
\hline 4 & Cinema & 10 & 8.92 \\
\hline 5 & Computer & 7 & 6.25 \\
\hline \multirow{4}{*}{6} & Internet & 6 & 5.35 \\
\cline { 2 - 4 } & Radio & 6 & 5.35 \\
\cline { 2 - 4 } & Combination & 6 & 5.35 \\
\hline 7 & Newspapers & 4 & 3.57 \\
\hline 8 & Printing/writing & 3 & 2.67 \\
\hline 9 & DVD & 1 & 0.89 \\
\hline & Total & 112 & 100 \\
\hline
\end{tabular}


In particular, the Book category rises to the first position of the editors' Media themes. We recorded 38 publications in total - a percentage of 33.9 - the main references of which pertain to book presentations (10 publications), book suggestions ( 6 publications) and book reviews in combination with the benefits of books to people (one publication). In their articles, the students journalists stress the value, profitability and usefulness of a good book (3 publications), while they underline the characteristics of good and bad books (one publication), they replicate book extracts by great authors and make references to them (4 publications). They also write about the new Primary school books and present their advantages and disadvantages (3 publications), they refer to the International Children's Book Day (3 publications) and write letters to their favourite children's book authors (3 publications). In addition, they inform about the new additions to the school library (2 publications) and make tribute articles to children's literature authors (one publication). They conduct and present a research on book preferences of parents and students (one publication), while they also write articles about students' best friend, the book (one publication).

Ranking second in children's preferences is the Television category. In total, 20 publications are recorded - a percentage of 17.8 - and the children's main references relate to the advantages and disadvantages of the television, excessive television viewing and their suggestions to parents and teachers ( 7 publications), the TV program (5 publications) and more specifically they suggest television series and analyze the scenario (in 2 publications). They also inform about the Eurovision song contest in 2 publications, they criticize the newscasts and commercials and stigmatize the influence and the urge to consume that they create ( 2 publications), they comment on the displeasing news and the politicians that monopolize the split screens in newscasts, or the social problems that newscasts discard (one publication). They write about the invention of the television in one publication, they appeal to journalists to stop showing images of children for the sake of ratings in one publication, they present a research on television with questions as to what children watch in one publication and they criticize programs in one publication. Finally, they talk about the children's relations to television, violent programs and the creation of a poster in their class in one publication, and finally they provide an update on the participation of school and teachers in television programs in one publication.

The Mobile phone category is found at the third position of the editors' preferences. We recorded a total of 11 publications - a percentage of 9.8 - in which the editors discuss issues pertaining to the negative effects and risks for children and adult health, whereas they underline the need for reasonable use for everyone's safety ( 5 publications) and an appeal for the sensitization of pupils so that mobile phone base station antennas be removed from their school (one publication). The young editors' pens belittle students' schoolbags that are now designed with mobile phone pockets, they refer to students' school break chats regarding mobile phone models, and they analyze the endless capabilities of mobile phones and ask for a reasonable use mainly by children (one publication). Moreover, they refer to the effortless manner of communication, its use by children and the risks involved in excessive use mainly regarding children and they reproach children's practice to buy mobile phones for reasons of fashion and personal display (one publication). They present their investigation to children 
and adults and underline the detrimental effects on health asking for reasonable use (one publication), whereas in another research they ascertain that $47 \%$ of their school pupils possess a mobile phone and from these a $63 \%$ use it for fashion and public demonstration (one publication as well) and finally, they condemn adults' practice of buying children mobile phones as approbation (one publication).

Cinema is found at the fourth position in children's preferences. We recorded 10 publications altogether - a percentage of 8.9 - in which references have mostly to do with film suggestions and descriptions of favourite films (4 publications), with educational school programs regarding cinema ( 3 publications), information about the first film projection in the world (one publication), the Thessaloniki Film Festival and its projection schedule (one publication) and positive review of films (one publication).

Coming fifth in children's favourites is the Computer category. A total number of 7 publications were recorded - a percentage of 6.2 - with references focusing on school subjects through computers and software (one publication), games they played on school computers (1 publication), news about offering computers gratuitously to students who earned Approbation with Distinction, computer lessons from the Parents' Association and comments on learning through computers (3 publications). They also discuss computer hackers in America - children criticize this phenomenon (one publication) - whereas in another publication they attempt to answer the question whether computers are a blessing or a curse, referring to the advantages and disadvantages and focusing on issues of isolation and poor scholastic performance due to excessive computer game time. However, they conclude that the advantages offered by the computer exceed in value than the disadvantages.

Ranking sixth in children's preferences are 6 publications altogether (a percentage of 5.3\%), with three categories in a tie: Internet, Radio and Combination of Media. In Internet, citations relate to the culture of the internet, instructions about online security and the friendships formed by children through the internet, underlining the attention children must pay on such issues (2 publications), teleconferencing and tele-teaching between two schools (4 publications). In Radio, pupil journalists mention their positive experience from participating in a radio broadcast (one publication), the 5 best music Greek and foreign songs (2 publications), the invention of the radio and the changes in news updates and entertainment (one publication), the radio shows that children listen and should listen during the weekend, suggesting certain programs on the FM dial and certain stations ( 2 publications). In the Combination of Media category, editors discuss their research in the school ground regarding children's views on basic sources of education, information and news, claiming to be the internet, books and newspapers (one publication), they comment on today's children's heroes projected by the Media and they criticize their extraordinary powers (one publication). What is more, they write articles about the invention of the television and the videocassette recorder and comment on them (one publication), they compare the two Media, Books and Television, while they underline the benefits of books and the detriments of television viewing (one publication). They also write articles about childhood violence and reproach the bad use of television, video games and violent films on television (one publication), they publish international studies regarding the television and computer, focusing on problems of 
vision, communication, isolation that created by the products of this technology (one publication).

Newspapers come seventh at children's preferences. Four publications were recorded in total - a percentage of 3.5 - and their references appertain to the identity of the first newspaper in the world (one publication), the newspapers of the Greek Revolution of 1821 (one publication), the award given to their school newspaper and its promotion from the Primary school language book (one publication) and the newspapers sent by other schools (one publication).

At the eighth position we find the Printing/writing category. Three publications were recorded in total (a percentage of 2.6) and their references bear upon the invention of printing ( 2 publications), providing historical data as to the evolution of writing and referring to the contribution of printing in knowledge and communication, and the inventor Johannes Gutenberg (one publication) yielding information about his life and invention.

Lastly, in the ninth position of the editors' favorites we encounter the category of the $D V D$, including only one publication - a percentage of 0.8 - which refers to evenings spent viewing certain good films on DVD.

\subsection{Quantitative classification of publications by Axes}

The analysis of our sample according to the axes (A) Old/traditional Media, (B) New Media and (C) Combination of Old/traditional and New Media produced tables 6 and 7 about the front and inside pages respectively.

Table 6. "Old/traditional" and "New" Media in the front page

\begin{tabular}{|l|l|l|l|}
\hline Axes & Categories & $\mathrm{n}$ & $\%$ \\
\hline \multirow{4}{*}{ Old/traditional Media } & Book & 2 & $(3)$ \\
\cline { 2 - 4 } & Television & 1 & 50 \\
\hline \multirow{4}{*}{ New Media } & Computer & 2 & $(3)$ \\
\cline { 2 - 4 } Total & Mobile phone & 1 & 50 \\
\hline
\end{tabular}

Table 6 demonstrates that (a) the publications about the "old" and "new" Media share a 50\% presence on each axis and (b) only 4 categories of Media appear on the front pages, with the Book and Computer categories in particular outnumbering the rest. 


\section{Macrothink}

Table 7. "Old/traditional" and "New" Media in the inside pages

\begin{tabular}{|c|c|c|c|}
\hline Axes & Categories & $\mathrm{n}$ & $\%$ \\
\hline \multirow{8}{*}{$\begin{array}{l}\text { Old/traditional } \\
\text { Media }\end{array}$} & Book & 36 & \multirow{8}{*}{$\begin{array}{l}(80) \\
75.47\end{array}$} \\
\hline & Television & 19 & \\
\hline & Cinema & 10 & \\
\hline & Radio & 6 & \\
\hline & Newspapers & 4 & \\
\hline & Printing/writing & 3 & \\
\hline & Television-Cinema & 1 & \\
\hline & Television-Video & 1 & \\
\hline \multirow[b]{4}{*}{ New Media } & Mobile phone & 10 & \multirow{4}{*}{$\begin{array}{l}(22) \\
20.75\end{array}$} \\
\hline & Internet & 6 & \\
\hline & Computer & 5 & \\
\hline & DVD & 1 & \\
\hline \multirow{4}{*}{$\begin{array}{l}\text { Combination of } \\
\text { "old/traditional" } \\
\text { and "new" Media }\end{array}$} & Book-Television & 1 & \multirow{4}{*}{$\begin{array}{l}(4) \\
3.77 \\
\end{array}$} \\
\hline & Television-Videogames-Cinema & 1 & \\
\hline & Television-Computer & 1 & \\
\hline & Internet-Book-Newspapers & 1 & \\
\hline Total & & 106 & 100 \\
\hline
\end{tabular}

The conclusion from reading table 7 is that in the inside pages of newspapers the publications about the "old/traditional" Media are far more numerous than the others by a staggering rate of $75.4 \%$. A clearly smaller amount of publications focus on issues pertaining to the "new" Media (20.7\%), whereas sporadic publications (3.7\%) appear to relate to the combination of "old" and "new" Media.

The overall table 8 presents all publications on front and inside pages collectively, corroborating the aforementioned results in the aggregate data of the sample. 
Table 8. "Old/traditional" and "New" Media in the columns of the school newspapers

\begin{tabular}{|c|c|c|c|}
\hline Media & Categories & $\mathrm{n}$ & $\%$ \\
\hline \multirow[b]{8}{*}{ Old/traditional Media } & Book & 38 & \multirow[b]{8}{*}{ (83) 74.1} \\
\hline & Television & 20 & \\
\hline & Cinema & 10 & \\
\hline & Radio & 6 & \\
\hline & Newspapers & 4 & \\
\hline & Printing/writing & 3 & \\
\hline & Television-Cinema & 1 & \\
\hline & Television-Video & 1 & \\
\hline \multirow[b]{4}{*}{ New Media } & Mobile phone & 11 & \multirow[b]{4}{*}{ (25) 22.32} \\
\hline & Computer & 7 & \\
\hline & Internet & 6 & \\
\hline & DVD & 1 & \\
\hline \multirow{4}{*}{$\begin{array}{l}\text { Combination } \\
\text { "old/traditional" and } \\
\text { "new" Media }\end{array}$} & Book-Television & 1 & \multirow[b]{4}{*}{ (4) 3.57} \\
\hline & $\begin{array}{l}\text { Television-Videoga } \\
\text { mes-Cinema }\end{array}$ & 1 & \\
\hline & $\begin{array}{l}\text { Television-Comput } \\
\text { er }\end{array}$ & 1 & \\
\hline & $\begin{array}{l}\text { Internet-Book- } \\
\text { Newspapers }\end{array}$ & 1 & \\
\hline Total & & 112 & 100 \\
\hline
\end{tabular}

The main Media references of student-editors regard the "old/traditional" Media $(74.1 \%)$, with the Book outnumbering the rest and the Television following it. A clearly lesser percentage of publications focus on the "new" Media (22.3\%) and significantly few publications appear regarding the combination of "old" and "new" Media (3.57\%).

The analysis of the sample as to the axes of (A) Print Media, (B) Electronic Media and (C) Combination of Print and Electronic Media resulted in table 9 regarding the front pages and table 10 about the rest of the pages.

Table 9. Print and electronic Media in the front page

\begin{tabular}{|l|l|l|l|}
\hline Axes & Categories & $\mathrm{n}$ & $\%$ \\
\hline \multirow{4}{*}{ Electronic Media } & Computer & 2 & \\
\cline { 2 - 3 } & Mobile phone & 1 & \multirow{4}{*}{$(4)$} \\
\cline { 2 - 3 } & Television & 1 & 66.66 \\
\hline \multirow{3}{*}{ Print Media } & & & $(2)$ \\
\hline Total & Book & 2 & 33.33 \\
\hline
\end{tabular}

Table 9 demonstrates that the majority of children's Media publications on the front pages of newspapers refer to the electronic Media (66.6\%) with the Computer rising first, whereas a percentage of 33.3 make reference to the print Media and the Book in particular. 
Table 10. Print and electronic Media in the inside pages

\begin{tabular}{|c|c|c|c|}
\hline Axes & Categories & $\mathrm{n}$ & $\%$ \\
\hline \multirow[b]{11}{*}{ Electronic Media } & Television & 19 & \multirow{11}{*}{$\begin{array}{l}(61) \\
57.54\end{array}$} \\
\hline & Mobile phone & 10 & \\
\hline & Cinema & 10 & \\
\hline & Internet & 6 & \\
\hline & Radio & 6 & \\
\hline & Computer & 5 & \\
\hline & Television-Videogames-Cinema & 1 & \\
\hline & Television-Computer & 1 & \\
\hline & Television-Video & 1 & \\
\hline & Television-Cinema & 1 & \\
\hline & DVD & 1 & \\
\hline \multirow[b]{3}{*}{ Print Media } & Book & 36 & \multirow{3}{*}{$\begin{array}{l}(43) \\
40.56\end{array}$} \\
\hline & Newspapers & 4 & \\
\hline & Printing/writing & 3 & \\
\hline \multirow{2}{*}{$\begin{array}{l}\text { Combination of print and electronic } \\
\text { Media }\end{array}$} & Book-Television & 1 & $(2)$ \\
\hline & Internet-Book-Newspapers & 1 & 1.88 \\
\hline Total & & 106 & 100 \\
\hline
\end{tabular}

Table 10 reveals that children's publications on inside pages concerning the electronic Media have a clear precedence (57.5\%) over those regarding the print Media (40.5\%), while the combination of print and electronic Media is meager (1.88\%). The publications regarding the Television in the electronic Media are more numerous, whereas the publications concerning the Book outnumber the others in print Media.

Table 11 presents the collective findings of our research in relation to the aforementioned axes both on the front and the inside pages. 


\section{Ml Macrothink}

Table 11. Print and electronic Media in the columns of the school newspapers

\begin{tabular}{|c|c|c|c|}
\hline Axes & Categories & $\mathrm{n}$ & $\%$ \\
\hline \multirow[b]{11}{*}{ Electronic Media } & Television & 20 & \multirow{11}{*}{$\begin{array}{l}(65) \\
58.03\end{array}$} \\
\hline & Mobile phone & 11 & \\
\hline & Cinema & 10 & \\
\hline & Internet & 6 & \\
\hline & Radio & 6 & \\
\hline & Computer & 7 & \\
\hline & Television-Videogames-Cinema & 1 & \\
\hline & Television-Computer & 1 & \\
\hline & Television-Video & 1 & \\
\hline & Television-Cinema & 1 & \\
\hline & DVD & 1 & \\
\hline \multirow[b]{3}{*}{ Print Media } & Book & 38 & \multirow{3}{*}{$\begin{array}{l}(45) \\
40.17\end{array}$} \\
\hline & Newspapers & 4 & \\
\hline & Printing/writing & 3 & \\
\hline \multirow[b]{2}{*}{ Combination of print and electronic Media } & Book-Television & 1 & (2) \\
\hline & Internet-Book-Newspapers & 1 & 1.78 \\
\hline Total & & 112 & 100 \\
\hline
\end{tabular}

Table 11 also confirms once again in the aggregate data of the sample, both on the front and the inside pages, the numeric predominance of publications regarding the electronic Media by a percentage of 58.0 and Television ranking first, followed by the Mobile phone and the Cinema. The publications that make reference to the Print Media have a percentage of 40.1 with the Book significantly outnumbering the Newspapers and Printing.

\section{Discussion}

The analysis of our sample shows that Media publications find their position in school newspapers' columns and make their presence noticeable more on the inside pages of newspapers rather than the front pages. The fact that the vast majority of publications is found on the inside pages of newspapers demonstrates a popular practice of the editors that reveals what they believe is important enough to be published /highlighted on their front page.

The existence of a regular column about Media issues is very limited, but its content indicates the tactics of those involved in school publications in order to maintain a Regular column only for Books, for their book suggestions/presentations and for no other Medium.

On the front page:

The analysis demonstrated the predominance of the publications regarding the electronic Media, while the "old/traditional" and the "new" Media are in a tie. As to the categories, the publications about the Book and the Computer are also in a tie.

On the inside pages: 
The numerical predominance of the publications regarding the "old/traditional" and the electronic Media is evident, whereas the publications about the Books outnumber the rest.

\section{Collectively:}

The overall collection and classification of the publications in Media categories pointed out the Book category as the first in editors' preferences, with the Television following, and as regards to the axes on one hand it stressed the remarkable numeric predominance of the "old/traditional" Media in children's Media references (with Books rising first) and on the other hand the clear supremacy of the electronic Media in students' journalistic articles, with the Television ranking first in their journalistic explorations regarding the electronic Media.

The research findings are equally impressive as to the content of the publications. Student journalists write mostly about the negative effects of the television and the mobile phone, they reproach advertising and family practices regarding the most popular Media of childhood.

Many researchers have underlined the predominance of the television in childhood (Suess et al, 1998; Lemish et al, 1998), but also the children's growing preference to the computers (Rideout et al, 1999). In their own Medium, however, student journalists give precedence to the Book which leads to justified questions: does a school newspaper ultimately constitute the place that creates attitudes/ identities/ perspectives? Is it the place where young editors create/ recreate models, values and behaviours? Is it the tribune that provides children with the possibility to take a critical stand against the Media and their messages and confront them as citizens, not children or learners in the narrow frame of the school? (Freinet, 1977; Alberti, 1986; Poslaniek, 1990; Bowen \& Tantillo, 2002; Kolodzy, 2006). The answers are rather affirmative and justifiably lead us to the basic aim "of all early didactic approaches to the Media, that aimed at educating pupils in discerning between "valuable" entertainment and "cheap" fun, between art and kitsch, between the elevated, authentic culture and the vulgar sub-culture of the Media, thus rendering teachers the privileged guardians and interpreters of what is Good, Real and Beautiful" (Paschalidis, 2000:119-120). In their newspapers students journalists take a critical stand against the Media and do not hesitate to reproach negative practices and to focus on the negative aspects of the Media. This fact also concurs with the findings from the international bibliography regarding the remarkable knowledge and ability that minors demonstrate in relation to the Media (Hodge \& Tripp, 1986; Willis, 1990; Buckingham, 1993a, 1993b), proving that they do not stand credulously and uncritically against the Media messages.

The qualitative analysis of our sample revealed the boldness that children exhibit in their publications to comment on, criticize and discuss the advantages and disadvantages of the Media, to investigate the school and social environment and gather people's views regarding the Media, to promote the benefits of books, to encourage and advocate a Media choice that is different from the one depicted in the studies about children's preferences in the Media, explaining at the same time and supporting their views. The titles used by editors about each Medium are indicative, a fact that connotes their general attitude regarding each Medium. We gleaned some of them: "Don't you have a mobile phone? That's strange!!!, Well done! I'll 
buy you a mobile phone!!, Journalists, stop..." Ponies with pens $3 / 2005$. "Shall we go to the cinema?" The pen of the Fifth, June 2007. "Company with the FM dial..." In a few words, 12/2006. "Mobile phones radiate and kill", The little room, 7/2006. "Television and its effects". Flutters, 127/2006. "Computers: a curse or a blessing? School pen, 7/2007. "Changes in our school: new computers in every classroom". Velo Pupils' brushwork, $7 / 2006$.

Naturally, it should not be forgotten that the publication of a school newspaper is among others a learning process based on the principles of problem solving (Abercrombie, 1979; Barrows, 1996: 3-13; Boyd-Bell, 2005; Boyd-Bell, 2002; Burns, 1997: 59-72; Burns \& Hazell, 1999: 56-71) and as such it should be evaluated according to the general and specific principles of the education sciences (Valsamidou \& Kyridis, 2009:85). School newspaper, however, constitutes an indicator and a writing sample of young editors regarding crucial and important social, communal and educational issues. According to Rolnicki, Dow Tate and Taylor (2001:xi), student journalists cover today's issues that may become the main points of national or international history, whether they write a report for their school newspaper, the magazine, the webpage or their radio broadcast. Therefore, if according to Tuchman (1978:6) the Media provides us with the news we wish to know, need to know and must know, then the school paper news provide children with what they want to know, need to know and must know.

"How about publishing a newspaper? (...) The proposal was accepted with joy and enthusiasm by all the children. (...)

Besides, every day we see on television things that frighten and trouble us. We rarely feel glad about what we hear. We would also like to express our views about everything happening around us, because we believe that we are a part of our society as well..."

"The pen of the Fifth", Fifth Primary School of Giannitsa Greece, issue 1, December 2002, Front page.

\section{Acknowledgement}

Special thanks to the following people for their help in collecting the newspaper issues (2006): Ms Elena Zygouri and Mr John Tzikas, school advisors in primary education, Mr Theodore Telopoulos, head of Scientific - Pedagogical Guidance in Central Macedonia, Mr Stavros Papoutsis, head of Primary Education Office and the headmasters and educational encouragers of the newspapers of the primary schools that are mentioned bellow.

\section{References}

Abercrombie, M. L. A. (1979). Aims and Purpose of Small Group Teaching. Society for Research into Higher Education. London. AUT University Calendar (2006). Auckland: AUT University.

Adaloglou, K. (1994). Students' personal creation through expression in the language class. The Teachers' Club, 8:24-25 (in Greek). 


\section{Macrothink}

Journal of Studies in Education

ISSN 2162-6952

2012, Vol. 2, No. 2

Alberti, A. (1986). Issues in Didactics. A dictionary of the basic terms of modern didactics. Athens: Gutenberg (in Greek).

Bandin L. (1977). L' analyse de contenu. Paris: PUF.

Barrows, H. S. (1996). Problem-based learning in medicine and beyond: A brief overview. In L. Wilkerson, W. Gijselaers (Eds.), Bringing problem-based learning to higher education: Theory and practice. New Directions for Teaching and Learning Series, 68 (pp.3-11). San Francisco: Jossey-Bass.

Berelson, B. (1952). Content Analysis in Communication Research. Glencoe, Illinois: Free Press.

Bowen, C. P., \& Tantillo, S. H. (2002). NCTE/IRA Standards in Classroom Journalism Projects. Urbana, Ill.: NCTE and JEA.

Boyd-Bell, S. (2002). Improving learning outcomes for journalism students - a tutor's perspective. Unpublished masters research paper. Auckland: School of Education, Auckland University of Technology.

Boyd-Bell, S. (2005). Experiential learning in journalism: A student view. Paper presented at the Journalism Education Association (JEA) conference, Gold Coast, Old, November 29-December 3.

Buckingham, D. (1993a). Changing Literacies: Media Education and Modern Culture. London: Tufnell Press.

Buckingham, D. (1993b). Children talking television: the making of television Literacy. London: Falmer Press.

Buckingham, D. (2003). Media Education: Literacy, Learning and Contemporary Culture. Cambridge: Polity Press and Blackwell Publishing Ltd.

Burns, L. S. (1997). Problem-based Learning (PBL) and journalism education: Is it new jargon for something familiar? Australian Journalism Review, 19(2), 59-72.

Burns, L. S., \& Hazell, T. (1999). Problem-Based Learning, Youth Suicide and Media's Response. Ability. Asia Pacific Media Educator, 6, 56-71.

Curley, K. (1990). Content Analysis. In: Asher E. The Encyclopedia of Language and Linguistics. Edinburgh: Pergamon Press.

De Sola Pool, I. (1959). Trends in Content Analysis. Urbana: University of Illinois Press.

Dictionary of Social Sciences. (1972). Under the auspices of UNESCO, Greek edition, vol. II. Athens: Nikas - Tegopoulos (in Greek).

Freinet, C. (1977). The School of the People. (Translated by K. Denaxa-Venieratou). Athens: Odysseas (in Greek).

Giddens, A. (2002). Sociology. Athens: Gutenberg (in Greek). 


\section{Macrothink}

Journal of Studies in Education

ISSN 2162-6952

2012, Vol. 2, No. 2

Graff, P. (2003). Standards in the Journalism Classroom. State of Scholastic Journalism: Principal's Guide to Scholastic Journalism. University of Iowa: Quill and Scroll Foundation.

Grawitz, M. (1981). Methods des sciences sociales. Paris: Dalloz.

Hatzopoulos, G., Dania, Z., Raptou, M., \& Fragou, B. (2000). In T. Anthogalidou (Ed.) Newspaper in the frame of school: from theory to practice. Virtual School, The sciences of Education Online, 2(1). [Online] Available: http://www.auth.gr/virtualschool/2.1/Praxis/Hatzopoulos.html (November 15, 2008) (in Greek).

Hodge, B., \& Tripp, D. (1986). Children and Television: A semiotic approach. Cambridge: Polity Press.

Klapper, J. T. (1949). The Effects of Mass Media. New York: Columbia University Bureau of Applied Social Research.

Kolodzy, J. (2006). Convergence Journalism: Writing and Reporting Across the News Media. NA: Rowman \& Littlefield.

Krippendorff, K. (1980). Content Analysis: An introduction to its methodology. USA: Sage Publications.

Lemish, D., Drotner, K., Liebes, T., Maigret, E., \& Stald, G. (1998). Global Culture in Practice, A Look at Children and Adolescents in Denmark, France and Israel. European Journal of Communication, 13(4), 539-556. http://dx.doi.org/10.1177/0267323198013004006

Moscovici, S. (1970). La psychanalyse, son image et son public. Paris: PUF.

Mucchieli, R. (1988). L' analyse de contenu des documents et des communications. Paris: Les Editions ESF.

Palmquist, M. (1990). The lexicon of the classroom: language and learning in writing classrooms. Doctoral Dissertation, Carnegie Mellon University.

Paschalidis, G. (2000). Education and Mass Communication: Conditions and perspectives of teaching the Media of Mass Communication in Primary and Secondary Education. Pedagogical Review, 30, 111-136 (in Greek).

Poslaniek, C. (1990). Giving children the pleasure of reading (translated by S. Athini). Athens: Kastaniotis (in Greek).

Psychogios, K. (2003). What are the Mass Media. Athens: Communication and Society Kastanioti (in Greek).

Rideout, V. J., Foehr, U. G., Roberts, D. F., \& Brodie, M. (1999). Kids and Media at the New Millenium: Executive Summary. Menlo Park, CA: Kaiser Family Foundation.

Rolnicki, T., Dow Tate, C., \& Taylor, S. (2001). Scholastic Journalism. USA: Blackwell Publishing. 


\section{Macrothink}

Journal of Studies in Education

ISSN 2162-6952

2012, Vol. 2, No. 2

Suess, D., Suoninen, A., Garitaonandia, G., Juaristi, P., Koikkalainen, R., \& Oleage, J. A. (1998). Media use and the relationships of children and teenagers with their peer groups: A Study of Finnish, Spanish and Swiss Cases. European Journal of Communication, 13(4), 521-538. http://dx.doi.org/10.1177/0267323198013004005

Tuchman, G. (1978). Making the News: A study in the construction of reality. New York: Free Press.

Valsamidou, L., \& Kyridis, A. (2009). Big athletes, big games" and small journalists. Sports in school newspaper columns. Contemporary Education, 158, 71-87 (in Greek).

Veron, E. (1981). La construction des evenements. Paris: Les Editions de Minuit.

Vryzas, K., \& Tsitouridou, M. (2002). Children and adolescents versus the "old" and "new" Media. In M. Dimitrakopoulou (Ed.) Proceedings of the 3rd ETPE Conference "ICT in education”, vol. B. Athens: Kastaniotis, 107-118 (in Greek).

Weber, R. (1990). Basic Content Analysis. (2 ${ }^{\text {nd }}$ ed.).Newbury Park: Sage.

Willis, P. (1990). Common Culture: Symbolic Work at Play in the Everyday Cultures of the Young. Milton Keynes: Open University Press.

\section{Appendix I}

Greek Primary School newspaper titles

1) Ponies with... pens, Interscholastic pupil newspaper of the 5th district of Primary Education of the Larissa prefecture, LARISSA

2) Velo Students' Brushwork, Primary school of Velo, CORINTHIA

3) Cats with petals, 2nd Primary school of Lixouri, CEPHALLONIA

4) Communication, 2nd Primary school of Skydra, PELLA

5) The pen of the Fifth, 5th Primary school of Giannitsa, PELLA

6) Students' pens, 2nd Primary school of LARISSA

7) Students' speech, Primary school of Rizo, PELLA

8) Student's world, Primary school of Neo Petritsi, SERRES

9) In a few words, 4th Primary school of Naoussa, IMATHIA

10) Through children's eyes, 2nd Primary school of Nemea, CORINTHIA

11) Young reporters, Intercultural Primary school of Neoi Epivates, THESSALONIKI

12) Children's voices of Stimaga, Primary school of Stimaga, CORINTHIA

13) Early school bulletins, Primary school of Afratio, EUBOIA

14) The little bees, Primary school of Megali Panagia, CHALKIDIKI 


\section{Macrothink}

15) THE NEWchoroudakia, Primary school of Neochorouda, THESSALONIKI

16) The little room, 2nd Primary school of Rethymno, CRETE

17) The young reporters of Ioannina, 12th Primary school of IOANNINA

18) The students' world of the 7th, 7th Primary school of CHIOS

19) Children's world, Primary school of Limni Aidipsou, EUBOIA

20) Children's world, Primary school of Stavroupoli, THESSALONIKI

21) The world through children's eyes, 6th Intercultural and fulltime Primary school of Eleftherio Kordeliou, THESSALONIKI

22) School pen, 2nd Primary school of Pefka, THESSALONIKI

23) The Milakia, Primary school of MILOS

24) The desk, 10th Primary school of Evosmos, THESSALONIKI

25) Flutters, Primary school of Thymiana, CHIOS

26) Flutters, 1st Experimental Primary school of FLORINA

27) Flutters, 1st Primary school of CORINTH 